Int. J. Electrochem. Sci., 15 (2020) $371-381$

International Journal of

ELECTROCHEMICAL

SCIENCE

WWW.electrochemsci.org

\title{
Green Synthesis of Polypyrrole coated Manganesee(II) Vanadate Nanoflower Composite as Cathode Materials
}

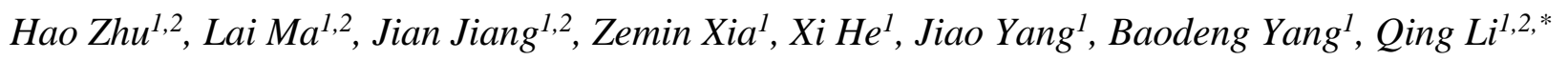

${ }^{1}$ Key Laboratory of Luminescent and Real-

Time Analytical Chemistry (Ministry of Education), School of Materials and Energy, Southwest University, Chongqing 400715, China

${ }^{2}$ Chongqing Key Laboratory for Advanced Materials and Technologies of Clean Energies, Southwest University, Chongqing 400715, China

*E-mail: qli@swu.edu.cn

doi: $10.20964 / 2020.01 .17$

Received: 8 August 2019 / Accepted: 8 October 2019 / Published: 30 November 2019

Flower-like $\mathrm{Mn}\left(\mathrm{VO}_{3}\right)_{2}$ precursors were synthesized by a hydrothermal method. Then they were wrapped by Polypyrrole (PPy) to obtain uniform $\mathrm{Mn}\left(\mathrm{VO}_{3}\right)_{2} @ \mathrm{PPy}$ nanoflower composites, which were consist of nanosheets with a length of 150-300 nm and covered with a layer of PPy. The $\mathrm{Mn}\left(\mathrm{VO}_{3}\right)_{2}$ @PPy nanoflower composites had a discharge capacity of $102.6 \mathrm{mAh} \mathrm{g}^{-1}$ range of $1.5-4.5 \mathrm{~V}$ at a current density of $0.1 \mathrm{~A} \mathrm{~g}^{-1}$ and a specific discharge capacity of $75.3 \mathrm{mAh} \mathrm{g}^{-1}$ range of $1.5-4.5 \mathrm{~V}$ when the current density was $1 \mathrm{~A} \mathrm{~g} \mathrm{~g}^{-1}$. After 500 cycles, their coulomb efficiency was close to $100 \%$, exhibiting good cycle performance. These results indicated that the $\mathrm{Mn}\left(\mathrm{VO}_{3}\right)_{2} @ \mathrm{PPy}$ nanoflower composites are promising as a lithium ion cathode material with good recycling performance.

Keywords: $\mathrm{Mn}\left(\mathrm{VO}_{3}\right)_{2} @ \mathrm{PPy}$; nanoflower; Cathode material

\section{$\underline{\text { FULL TEXT }}$}

(C) 2020 The Authors. Published by ESG (www.electrochemsci.org). This article is an open access article distributed under the terms and conditions of the Creative Commons Attribution license (http://creativecommons.org/licenses/by/4.0/). 